\title{
Isolation and identification of toxigenic and non-toxigenic fungi in samples of medicinal plants from the market
}

\author{
PEREIRA, C.G.'; SILVA, J.R.O.'; BATISTA, L.R. ${ }^{*}$ \\ Universidade Federal de Lavras - UFLA, Departamento de Ciência dos Alimentos, Laboratório de Microbiologia, \\ Campus, Lavras-MG, CEP: 37200-000. *luisrb@dca.ufla.br
}

\begin{abstract}
The consumption of preparations of medicinal plants has been increasing during the last decades in occidental societies. The presence of toxigenic fungi in a plant product may represent a potential risk of contamination, because of aflatoxins and ochratoxins. In this study, 12 samples of medicinal plants were analyzed in relation to the level of fungal contamination, and the presence of producers of ochratoxin A and aflatoxins was assessed by visualization of fungi using a cromatovisor in coconut milk. Most of the species found belong to the genus Cladosporium, Fusarium, Aspergillus and Penicillium. Species producing ochratoxin A were present in 2 samples (16.7\%), Melissa and Hibiscus. Species producing aflatoxin were found in samples of Jacaranda decurrens (8.33\%). This study suggests that herbs, if stored improperly, can provide the growth of fungi and should be examined before consumption.
\end{abstract}

Key words: Aspergillus. Penicillium. Moulds. Mycotoxin.

RESUMO: Isolamento e identificação de fungos toxigênicos e não toxigênicos em amostras plantas medicinais do comércio. $O$ consumo das plantas medicinais vem aumentando nas últimas décadas nas sociedades ocidentais, porém, a presença de fungos toxigênicos nestas plantas pode representar um risco em potencial de contaminação devido à produção de aflatoxinas e ocratoxinas. Neste trabalho, 12 amostras de plantas medicinais foram analisadas em relação ao nível de contaminação por fungos, enquanto a presença de produtores de ocratoxina $A$ e aflatoxinas foi avaliada pela visualização em cromatovisor dos fungos em meio de leite de coco. A maioria das espécies encontradas pertence aos gêneros Cladosporium, Fusarium, Aspergillus e Penicillium. Espécies produtoras de ocratoxina A estavam presentes em 2 amostras (16,7\%), Melissa e Hibisco. Espécies produtoras de aflatoxina foram encontradas na amostra de Carobinha (8,33\%). Este trabalho sugere que as ervas, sendo armazenadas inadequadamente, proporcionam o crescimento de fungos e, por isso, estes devem ser examinados antes do consumo.

Palavras chave: Aspergillus. Penicillium. Fungos. Micotoxinas.

\section{INTRODUCTION}

The natural products that have therapeutic activities were already being used since the dawn of civilization, have long been the primary means used for prevention, treatment and cure of human disease and animal (CHOI et al., 2002; VEIGA et al., 2005).

In Brazil, the use of medicinal plants to treat illnesses has its origin in indigenous cultures, black and immigrant Europeans, already knowing today a lot about its use by the popular wisdom. With scientific advances, this ancient practice gave way to synthetic drugs, falling into oblivion for more than 50 years (BUGNO et al., 2006), however, there has been a growing rediscovery of the value of medicinal plants not only because of some unforeseen side effects of many drugs artificial, but its high price, thus contributing to the resurgence of herbal therapy (through plants). As fungal organisms are widely distributed in the environment, may be present in soil, plants, decaying organic matter, water, air and dust, unprocessed products of animal or vegetable origin can become contaminated with a wide variety of fungal species and their toxic products (COSTA et al., 2009; PRADO et al., 2008; TASSANEEYAKUL et al., 2004). Knowing this, the consumption of natural drugs have made their use a public health problem because of the possibility of access to products without adequate conditions of use, without warranty of quality, safety and efficiency, fundamental to the 
recovery or preservation of health consumer.

Fungi can be dispersed by air, contamination of plants can occur both before and after harvest and during processing. Among the major genera found in Brazil include: Cladosporium, Fusarium, Aspergillus, Penicillium and Rhizopus. The presence of these fungi in herbal medicines can be harmful to human health, since these can cause mycotoxicosis, when introduced orally or other diseases when inhaled (KNEIFEL et al., 2002). The mycotoxins are considered to be among the most carcinogenic natural substances known (FREIRE; KOZAKIEWICZ, 2005). Species of Aspergillus, producers of aflatoxin, are very common in products such as medicinal plants (RIZZO et al., 2004).

According to the RDC n॰48, March 16, 2004, herbal medicines should be registered according to the norms of the National Health Surveillance Agency (ANVISA), being the search for microbiological contaminants also included in the recommendations of the World Health Organization (WHO), (ANVISA, 2004; WHO, 1992).

This study aimed to evaluate the presence of mycotoxin producing fungi in medicinal plants sold in the city of Lavras - MG.

\section{MATERIALS AND METHODS}

We analyzed 12 samples of medicinal plants, which were obtained in the local city of Lavras - MG. The products were chosen according to their popularity and commercial availability. Anis estrelado (Illicium verum), Boldo do Chile (Peumus boldus Molina), Carobinha (Jacaranda micrantha Cham.), Cavalinha (Equisetum arvense L.), Guaco (Mikania glomerata Spreng), Hibisco (Hibiscus sabdariffa Lineo), Ipê Roxo (Tabebuia impetiginosa), Melissa (Melissa officinalis L), Porangaba (Cordia salicifolia Cham), Quebra-pedra (Phyllanthus niruri L), Sete Sangria (Cuphea carthaginensis) and Transagem (Plantago spp).

\section{Assessment of fungal contamination}

For mycological analysis were homogenized $25 \mathrm{~g}$ sample of each plant with $475 \mathrm{ml}$ of peptone water in stomacher equipment. After homogenization, aliquots of $1 \mathrm{ml}$ were used to perform serial dilutions in three tubes containing $9 \mathrm{ml}$ of peptone water. Aliquots of $0,1 \mathrm{ml}$ of the dilutions were transferred to Petri dishes, in triplicate, containing the culture medium Dichloran Rose Bengal Chloramphenicol (DRBC) and incubated at $25{ }^{\circ} \mathrm{C}$ for 7 days. After incubation, fungal colonies were counted, recorded and the number of colony forming units (CFU) per gram were calculated as Samson et al.(2004).

For species identification we used the manual identification described by Klich (2002) and
Samson et al. (2004). The culture media used were Czapek Yeast Agar (CYA), Malt Extract Agar (MEA), Yeast Extract Sucrose (YES), at the temperatures recommended by the manual of identification. The toxigenic potential of isolates was evaluated in coconut-agar medium, second Lin and Dianese (1976), and incubated at $25 \pm 1^{\circ} \mathrm{C}$ for 5 days.

The frequency of occurrence of fungi found in the microbiota of the samples was calculated as in equation 1, second Mandeel (2005).

Occurence frequency $(\%)$

$$
=\left(\frac{\text { No. of fungal isolates on a drug sample }}{\text { Total no. of fungal isolates on all drug samples }}\right) \times 100 \text { (1) }
$$

\section{RESULTS AND DISCUSSION}

The risk from the presence of microorganisms in herbal drugs or other product intended for human consumption is due to the potential damage it might cause to consumers. In order to guarantee the quality and safety of these products in Brazil, the RDC Resolution n॰ 48, March 16, 2004 (BRASIL, 2004), states that the search for microbiological contaminants in herbal medicines should comply with pharmacopoeial specifications. Both the Brazilian Pharmacopoeia (2010) and U.S. Pharmacopeia (2005) set a maximum contamination by fungi of 2 $x 10^{2} \mathrm{CFU} / \mathrm{g}$ per product, to products for oral use.

Table 1 lists the fungi isolated from each sample with its respective level of contamination and toxigenic potential.

According to the results, it was found that $100 \%$ of the samples showed fungal contamination, and $41,66 \%$ (5 samples) had levels above the recommended limit and 58,34\% (7 samples) were within the standards. Bugno et al. (2005) analyzed 91 samples of vegetable drugs, consisting of 65 different plant species, noting a $63,1 \%$ percentage of samples with fungal populations exceeding $2 \times 10^{2} \mathrm{CFU} / \mathrm{g}$. Rocha et al. (2004), analyzed 20 samples of leaves of Cassia acutifolia Delile (Sene) and Peumus boldus Molina (Boldo-do-Chile), which showed $92.5 \%$ of fungal contamination, and 45\% (18 samples) had levels above the limit.

Filamentous fungi such as Aspergillus and Penicillium, found in virtually every environmental niche, have several species that produce toxic metabolites during its growth and development (BUGNO et al., 2005). Of 12 plants analyzed 83,3\% (10 samples) were contaminated with species of the genus Aspergillus. Rizzo et al. (2004) evaluated 152 samples of medicinal plants in Argentina, noting that $52 \%$ were contaminated by Aspergillus species. Samples Carobinha $\left(6,2 \times 10^{2} \mathrm{CFU} / \mathrm{g}\right)$, Guaco (3,5 x 103 CFU/g), Quebra-pedra (4,6 x 103 CFU/g) and Sete Sangria $\left(6,5 \times 10^{3} \mathrm{CFU} / \mathrm{g}\right)$ showed the highest levels of contamination. The frequency 
TABLE 1. Distribution of fungal contaminants, the level of contamination in the samples and toxigenic potential of medicinal plants.

\begin{tabular}{|c|c|c|c|}
\hline Sample & Contamination Level & Contaminant & Toxigenic Potential \\
\hline Anis Estrelado & Below 25 CFU/g & Fusarium and Cladosporium (C. cladosporioides) & - \\
\hline Boldo do Chile & Below 25 CFU/g & Fusarium & \\
\hline Carobinha & $6,2 \times 10^{2} \mathrm{CFU} / \mathrm{g}$ & $\begin{array}{l}\text { Aspergillus niger Agregados, Aspergillus niger, } \\
\text { Aspergillus foetidus and Aspergillus flavus }\end{array}$ & A. flavus \\
\hline Cavalinha & Below 25 CFU/g & Fusarium and $A$. fumigatus & - \\
\hline Guaco & $3,5 \times 10^{3} \mathrm{CFU} / \mathrm{g}$ & A. Níger & \\
\hline Hibisco & $1,85 \times 10^{2} \mathrm{CFU} / \mathrm{g}$ & A. flavus, $A$. ochraceus and $A$. foetidus & A. ochraceus \\
\hline Ipê Roxo & $3,5 \times 10^{2} \mathrm{CFU} / \mathrm{g}$ & A. niger, $A$. foetidus and $A$. niger Agregados & 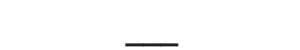 \\
\hline Melissa & $1,3 \times 10^{2} \mathrm{CFU} / \mathrm{g}$ & Penicillium funiculosum, $A$. ochraceus and $A$. went $i$ & A. ochraceus \\
\hline Porangaba & $5,5 \times 10 \mathrm{CFU} / \mathrm{g}$ & A. flavus, A. foetidus and $A$. niger Agregados & $\ldots$ \\
\hline Quebra-pedra & $4,6 \times 10^{3} \mathrm{CFU} / \mathrm{g}$ & A. niger Agregados & $\overline{-}$ \\
\hline Sete Sangria & $6,5 \times 10^{3} \mathrm{CFU} / \mathrm{g}$ & A. niger Agregados and $A$. foetidus & - \\
\hline Transagem & Below $25 \mathrm{CFU} / \mathrm{g}$ & A. foetidus and $A$. niger & \\
\hline
\end{tabular}

values of fungi (\%) were estimated to determine the abundance of isolates within a given sample of plant in relation to all species isolated from all samples. The results can be seen in figure 1.

The frequency values ranged from $3,7 \%$ to Boldo do Chile, Guaco and Quebra-Pedra to $14,8 \%$ for Carobinha that presented contamination by 4 fungal species found. Mandeel (2005) evaluated the frequency of fungal contamination in pepper with the results ranging from $0,9 \%$ to $23,75 \%$.

Through visualization of fungi in cromatovisor amid coconut milk, $A$. ochraceus (one per sample) producer of ochratoxin A was isolated from Melissa and Hibisco, and isolates from Carobinha, A. flavus (two in the sample), producer of aflatoxin.

Publications relating to the identification and quantification of fungi in herbal medicines in Brazil are scarce. Bugno et al. (2002), found contamination by Aspergillus and Penicillium in tea infusion, powder (guarana), fluid extract, tablets and capsules. However, show profiles similar to those of other countries. In Portugal, Martins et al. (2001) found the presence of filamentous fungi such as Aspergillus, Penicillium, Absidia, Mucor, Cladosporium and Paecilomyces in 62 samples of 7 different herbal medicines. Similar results were seen by Abou-Arab et al. (1999), Egypt and Efuntoye (1999), in Nigeria.

Food borne fungi are responsible for a high global incidence of mycotoxins, which are secondary metabolites produced by fillamentous fungi and involved in a toxic response called mycotoxicosis in human and higher animals when contaminated (FREIRE; KOZAKIEWICZ, 2005). Contamination of medicinal plants by toxigenic fungi and their mycotoxins pose a special hazard to health and can cause acute poisoning or chronic case of ingestion

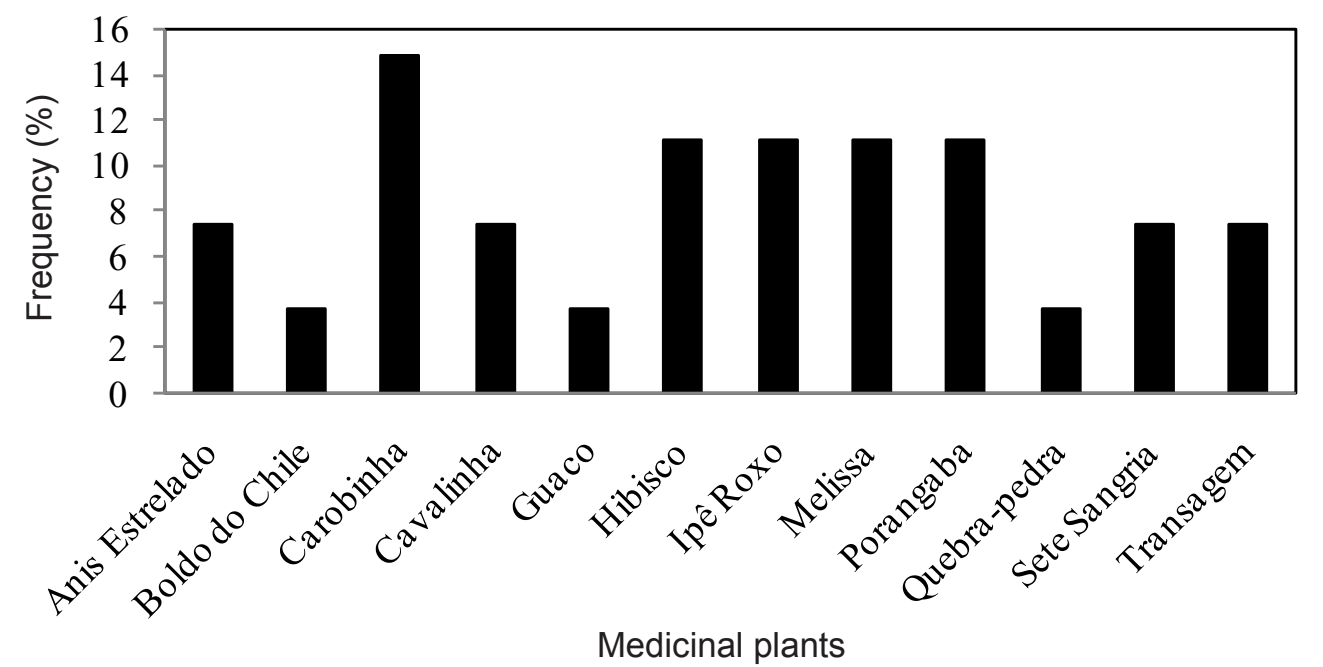

FIGURE 1. Occurrence frequency of fungal microbiota of all medicinal plants.

Rev. Bras. PI. Med., Campinas, v.17, n.2, p.262-266, 2015. 
of products contaminated with mycotoxins, even in the form of tea, they are extremely thermostable, not being decomposed by temperature of boiling water. Currently, synthetic fungicides are being used frequently in long-term storage, however most synthetic fungicides can cause residual toxicity, which makes their use on raw materials herbal undesirable (SINGH et al., 2008). Importantly, aflatoxins produced by Aspergillus have extremely high melting point, around $269{ }^{\circ} \mathrm{C}$, and present a potential carcinogen (WHO, 1979). According to the IARC (International Agency for Research on Cancer), mycotoxins are classified in group 1, defined as carcinogenic to humans (ABOU-ARAB et al., 1999; IARC 1993).

In Brazilian legislation, mycotoxins have not yet maximum permissible levels (LMT) to its presence in medicinal plants according to RDC $n^{\circ}$ 7, February 18, 2011, which establishes maximum permissible levels (LMT) for mycotoxins in food.

Currently, it is known that aflatoxin can cause, among other problems, cirrhosis, acute liver necrosis, hemorrhage, kidney, hepatitis B and serious injury to the skin. In addition, aflatoxin is considered a teratogenic agent, therefore, in pregnant women can cause irreversible harm to the fetus, and mutagenic, because the products of their metabolism in the body react with DNA at the cellular level by interfering with the immune system of individual infected, reducing thereby its resistance to diseases.

The herbal medicine in general is susceptible to fungal contamination during the process of planting and harvesting. In addition, improper storage and handling of these products can be a source of secondary contamination.

Some cares in the steps of the processing of medicinal plants are needed to reduce the microbial load, proper hand hygiene of handlers of medicinal plants, the material collected should be placed on a clean surface, the collection container should be cleaned, should to seek to remove impurities that may accompany the body or newly collected plant, drying the plant should be completed as quickly as possible, making it difficult to microbiological contamination, since the raw material is manipulated after harvest again. The site should be cleaned dry, well ventilated, protected from attack by insects and other animals and also without light. After, the material of packaging must be properly cleaned, stored in a dry, ventilated and protected from sunlight and the incidence of the entry of rodents and insects. There should be no direct contact of the pack with the floor, and this should be placed on a pallet to prevent moisture transfer and possible contact with animals (REIS; MARIOT, 2001). The training of farmers by trained professionals is necessary. Facts observed in practice, as the presence of fragments of insects, earth, wood, and microbiological contaminants, indicate that should take urgent education measures in the interests of efficiency and therapeutic safety.

\section{CONCLUSION}

The samples with higher fungal contamination were the Sete Sangria, Quebra-pedra and Guaco, and $41,66 \%$ in this study of medicinal plants did not meet the maximum acceptable by law. Among the fungi, the presence of Aspergillus was predominant $(83,3 \%)$. In the samples of Melissa and Hibisco detected the presence of Aspergillus ochraceus producing ochratoxin $\mathrm{A}$ and the sample Carobinha was detected the species Aspergillus flavus producing aflatoxin. Although the presence of toxigenic fungi in a product does not imply the detection of mycotoxins, their presence represents a potential risk of contamination. Knowing the increase in consumption of herbal products as alternative medicines and the risk of acquiring and using natural products contaminated with fungi and mycotoxins, it is necessary to establish appropriate standards for toxigenic fungi and mycotoxins in medicinal plants in order to reduce the risks to consumer health.

\section{REFERENCES}

ABOU-ARAB, A. A. K; KAWTHER, M. S.; EL TANTAWY, M. E.; BADEAA, R. I.; KHAYRIA, N. Quantity estimation of some contaminants in commonly used medicinal plants in the Egyptian market. Food Chemistry, v. 67, n. 4, p. 357-363, 1999.

BRASIL. Agência Nacional de Vigilância Sanitária. Resolução RDC no 7, de 18 de fevereiro de 2011. Dispõe sobre limites máximos tolerados (LMT) para micotoxinas em alimentos. Diário Oficial da União, Poder Executivo, Brasília, DF, 22 fev. 2011.

BRASIL. Agência Nacional de Vigilância Sanitária. Resolução RDC n॰48, de 16 de março de 2004. Dispõe sobre o registro de medicamentos fitoterápicos. Diário Oficial da União, Poder Executivo, Brasília, DF, 18 mar. 2004.

BUGNO, A.; AlMOdOVAR, A. A. B.; PEREIRA, T. C.; PINTO, T. J. A.; SABINO, M. Occurrence of toxigenic fungi in herbal drugs. Brazilian Journal of Microbiology, v. 37, n. 1, p. 47-51, 2006.

BUGNO, A.; BUZZO, A. A.; NAKAMURA, C. T.; PEREIRA, T. C.; MATOS, D.; PINTO, T. de J. A. Avaliação da contaminação microbiana em drogas vegetais. Revista Brasileira de Ciências Farmacêuticas, v. 41, n. 4, p. 491-497, 2005.

BUGNO, A.; MATOS, D.; PINTO, T. J. A. Contaminação fúngica em plantas medicinais. Revista Brasileira de Ciências Farmacêuticas, v. 38, n. 1, p. 87, 2002.

CHOI, D. W.; KIM, J. H.; CHO, S.Y.; KIM, D. H.; CHANG, S. Y. Regulation and quality control of herbal frugs in Korea. Toxicology, v. 181-182, p. 581-586, 2002. 
COSTA, A. K. F.; FREIRE, F. das C. O.; VIEIRA, I. G. P.; ANDRADE, J. A.; MENDES, F. N. P. Fungos associados à castanha-do-Brasil (Bertholletia excelsa Humb. \& Bompl) e ao amendoim (Arachis hypogaea L.) comercializados em Fortaleza (Ceará). Revista Ciência Agronômica, Fortaleza, v. 40, n. 3, p. 455-460, 2009.

EFUNTOYE, M.O. Mycotoxins of fungal strains from stored herbal plants and mycotoxin contents of Nigerian crude herbal drugs. Mycopathologia, v. 147, n. 1, p. 43-48, 1999.

FARMACOPÉIA Brasileira. 4. ed. São Paulo: Atheneu, 1988-1996.

FREIRE, F. C. O.; KOZAKIEWICZ, Z. Filamentous fungi, bacteria and yeasts associated

with cashew kernels in Brazil. Revista Ciência Agronômica, v. 36, n. 2, p. 249-254, 2005.

IARC. Evaluation of carcinogenic risks of chemical to humans. Some naturally-occurring substances: Food items and constituents. Heterocyclic aromatic amines and mycotoxins. IARC monographs, Lyon, France, 1993, p. 359-362.

$\mathrm{KLICH}, \mathrm{M}$. A. Identification of common Aspergillus species. Utrecht, Netherlands: Centraalbureau voor Schimmelcultures, 2002.

KNEIFEL, W.; CZECH, E.; KOPP, B. Microbial contamination of medicinal plants - a review. Planta Medica, v. 68, n. 1, p. 5-15, 2002.

LIN, M. T.; DIANESE, J. C. A coconut agar medium for rapid detection of aflatoxin production by Aspergillus spp. Phytopathology. v. 66, p. 1466-1469, 1976.

MANDEEL, Q. A. Fungal contamination of some imported species. Mycopathologia, v. 159, n. 2, p. 291-298, 2005.

MARTINS, H. M.; MARTINS, M. L.; DIAS, M. I.; BERNARDO, F. Evaluation of microbiological quality of medicinal plants used in natural infusions. International Journal of Food Microbiology, v. 68, n. 1, p. 149-153, 2001.

PRADO, G.; OLIVEIRA, M. S.; MOREIRA, A. P. A.; LIMA, A. de S.; SOUZA, R. de A.; ALVES, M. do C. Determinação de aflatoxina B1 em pimenta (Piper nigrum L.) e orégano (Origanum vulgare L.) por cromatografia em camada delgada e densitometria. Química Nova, v. 31, n. 3, 2008.

REIS, A.; MARIOT, A. Diversidade natural e aspectos agronômicos de plantas medicinais. 3 ed. Porto Alegre: UFRGS/UFSC, 2001, p. 39-60.

RIZZO, I.; VEDOYA, G.; MAURUTTO, S.; HAIDUKOWSKI, M.; VARSAVSKY, E. Assessment of toxigenic fungi on Argentinean medicinal herbs. Microbiology Research, v. 159, n. 2, p. 113-120, 2004.

ROCHA, L. de O.; SOARES, M. M. S. R.; CORRÊA, C. L. Análise da contaminação fúngica em amostras de Cassia acutifolia Delile (sene) e Peumus boldus (Molina) Lyons (boldo-do-Chile) comercializadas na cidade de Campinas, Brasil. Revista Brasileira de Ciências Farmacêuticas, v. 40, n. 4, p. 521-527, 2004.

SAMSON, R. A., HOEKSTRA, E. S., FRISVAD, J. C. Introduction to Food - and Airborne Fungi. $7^{\text {th }}$ ed.: Centraalbureau voor Schimmelcultures, Utrecht, The Netherlands, 2004.

SINGH, P.; SRIVASTAVA, B.; KUMAR, A.; DUBEY, N. $\mathrm{K}$. Fungal contamination of raw materials of some herbal drugs and recommendation of Cinnamomum camphora oil as herbal fungitoxicant. Microbial Ecology, v. 56, n. 3, p. 555-560, 2008.

TASSANEEYAKUL, W.; RAZZAZI-FAZELI, E.; PORASUPHATANA, S.; BÖHM, J. Contamination of aflatoxins in herbal medicinal products in Thailand. Mycopathologia, v. 158, n. 2, p. 239-244, 2004.

THE UNITED STATES PHARMACOPEIA. 28. ed. Rockville: United States Pharmacopeial Convention, 2005.

VEIGA Jr., V. F.; PINTO, A. O.; MACIEL, M. A. M. Plantas medicinais: cura segura? Química Nova, v. 28, n. 3, p. 519-528, 2005.

WORLD HEALTH ORGANIZATION. Mycotoxins. Geneva: WHO, 1979.

WORLD HEALTH ORGANIZATION. Quality control methods for medicinal plants materials. Geneva: WHO, 1992. 